\section{Interventions to promote health through increased physical activity ${ }^{1}$}

Key words: guidelines, exercise, physical fitness, public health policy.

\footnotetext{
Based on: Increasing physical activity. A report on recommendations of the Task Force on Community Preventive Services. MMWR Morb Mortal Wkly Rep 2001;50(RR-18):1-14. Available from: http:/ /www. cdc.gov/mmwr/ [Internet site]. Accessed 15 November 2001.
}

Regular physical activity has numerous health benefits, but only about one-fourth of the adults in the United States of America follow the recommendations of performing either 30 minutes of moderateintensity activity at least 5 days per week or 20 minutes of vigorous-intensity physical activity 3 or more days per week. Further, many adults and adolescents in the United States report no regular moderate or vigorous physical activity (Table 1 ).

To help remedy this situation, a group of health experts in the United States conducted a systematic review of possible interventions to increase physical activity. The group, called the Task Force on Community Preventive Services, is convened by but independent of the United States Government's Department of Health and Human Services.

The new report that the Task Force prepared is entitled "Increasing Physical Activity." It is one in a series of topics included in the "Guide to Community Preventive Services: Systematic Reviews and Evidence-Based Recommendations." Called the "Community Guide" for short, that complete resource will be published in the future and will include multiple systematic reviews, each focusing on a different preventive health topic.

With this report on physical activity, the Task Force followed the standard procedure that the group has for other health topics. A multidisciplinary team conducted a review by: 1) developing an approach to organizing, grouping, and selecting interventions; 2) systematically searching for and retrieving evidence concerning the interventions; 3) assessing the quality of and summarizing the strength of the body of evidence on effectiveness; 4) summarizing information regarding other evidence; and 5) identifying and summarizing research gaps.

The Task Force team generated a comprehensive list of interventions, from which a priority list of interventions for review was developed. Factors for consideration included the public health consequences (i.e., number of persons affected), the practicality of application, and the need that persons who promote physical activity have for information regarding each intervention. Because of time and resource constraints, the Task Force could not review certain interventions such as ones oriented toward health care providers or structured exercise classes that were not part of multicomponent community-based interventions. 
TABLE 1. Levels of physical activity in the United States of America (percentage of population) and objectives for increasing those activity levels by 2010

\begin{tabular}{|c|c|c|c|}
\hline Objective & Population & Baseline level $^{a}$ & 2010 objective \\
\hline $\begin{array}{l}\text { No leisure-time physical activity } \\
\text { Moderate physical activity for } \geq 30 \text { min regularly, }\end{array}$ & Adults & $40 \%$ & Reduce to $20 \%$ \\
\hline $\begin{array}{l}\text { preferably daily } \\
\text { Moderate physical activity for } \geq 30 \text { min on } \geq 5 \text { of previous }\end{array}$ & Adults & $15 \%$ & Increase to $30 \%$ \\
\hline 7 days & Adolescents & $27 \%$ & Increase to $35 \%$ \\
\hline $\begin{array}{l}\text { Vigorous physical activity that promotes development and } \\
\text { maintenance of cardiorespiratory fitness on } \geq 3 \\
\text { days/week for } \geq 20 \text { min/occasion }\end{array}$ & Adults & $23 \%$ & Increase to $30 \%$ \\
\hline $\begin{array}{l}\text { Vigorous physical activity that promotes development and } \\
\text { maintenance of cardiorespiratory fitness on } \geq 3\end{array}$ & & & \\
\hline days/week for $\geq 20$ min/occasion & Adolescents & $65 \%$ & Increase to $85 \%$ \\
\hline Daily school physical education & Adolescents & $29 \%$ & Increase to $50 \%$ \\
\hline View television for $\leq 2$ hours on a school day & Adolescents & $57 \%$ & Increase to $75 \%$ \\
\hline Trips of $\leq 1$ mile $(1.6 \mathrm{~km})$ made by walking & Adults & $17 \%$ & Increase to $25 \%$ \\
\hline Trips to school of $\leq 1$ mile $(1.6 \mathrm{~km})$ made by walking & Children and adolescents & $31 \%$ & Increase to $50 \%$ \\
\hline Trips of $\leq 5$ miles $(8.0 \mathrm{~km})$ made by bicycling & Adults & $0.6 \%$ & Increase to $2.0 \%$ \\
\hline Trips to school of $\leq 2$ miles $(3.2 \mathrm{~km})$ made by bicycling & Children and adolescents & $2.4 \%$ & Increase to $5.0 \%$ \\
\hline
\end{tabular}

Source: Healthy People 2010 (1).

a Depending on the specific objective, the baseline years range from 1995 to 1999 . Certain estimates are age-adjusted to the year 2000 standard population.

The Task Force recommendations are intended for use both in planning interventions to increase physical activity and in evaluating existing programs.

To find relevant research studies, the Task Force conducted searches of computerized databases that included MEDLINE as well as ones dealing with sports and the social sciences. To be eligible, the studies had to: a) be primary investigations of interventions selected for evaluation rather than, for example, guidelines or reviews; $b$ ) be published in English during 1980-2000; c) be conducted in established "market economies" (mainly the United States, Canada, Western Europe, Japan, Australia, and New Zealand); and d) compare outcomes among groups of persons exposed to the intervention with outcomes among groups of persons not exposed or less exposed to the intervention, whether the study design included a concurrent or before-and-after comparison. To make its recommendations, the Task Force required that studies demonstrate improvements in physical activity behavior outcomes (e.g., increased time spent walking) or increases in selected fitness measures (e.g., increased aerobic capacity).

\section{RECOMMENDED INTERVENTIONS}

The Task Force recommended a total of six interventions: two informational ones, three behavioral and social approaches, and one environmental and policy method.

\section{Informational approaches}

The first of the informational approaches that the Task Force recommended was communitywide campaigns. These large-scale, high-intensity efforts utilize sustained high visibility to disseminate messages promoting physical activity behavior. The media used included television, radio, newspaper columns and inserts, and short movie-theater film presentations. The campaigns were multicomponent and incorporated such activities as support and self-help groups, physical activity counseling, risk factor screening and education, community events, and the creation of walking trails.

The second informational approach recommended was point-of-decision prompts to encourage using stairs. This involved placing motivational signs close to elevators and escalators to persuade individuals to use nearby stairs for health benefits and weight loss. This approach was applied in such settings as shopping malls, university libraries, and train, subway, and bus stations.

\section{Behavioral and social approaches}

School-based physical education (PE) was strongly recommended for pupils in elementary school and high school. Some of the interventions assessed involved modifying curricula and policies to increase the amount of moderate or vigorous activity in the PE classes. Other interventions increased the amount of time spent in the PE classes 
or raised the amount of time in such classes that students were active. Some of the interventions included changing the activities that were taught, for example replacing softball with soccer or another more-vigorous activity. In other cases, the same games were played but with modified rules to increase the students' activity levels.

Another strongly recommended approach was individually adapted health behavior change programs. Such programs were tailored to individuals' readiness for change, or to their specific interests. They helped persons incorporate physical activity into their daily routines, by teaching such behavioral skills as goal-setting and self-monitoring, building social support, self-reward and selftalk, and relapse prevention. These interventions were delivered in group settings or by mail, telephone, or other media.

The third of the recommended behavioral and social approaches was social support interventions in community settings. These efforts focused on building and maintaining social networks that encouraged physical activity. The interventions included such activities as setting up a "buddy system" for two people to exercise together, contracting with another person to complete specified levels of physical activity, and setting up walking groups or other activity groups providing friendship and support.

\section{An environmental/policy approach}

The Task Force strongly recommended one environmental and policy approach, the creation of or enhanced access to places for physical activity, in combination with informational outreach activities. Access to places for physical activity was created or improved by building trails or other facilities or by reducing the fees for using them and increasing the time available for their use. Other programs provided training in the use of exercise equipment, or such incentives as risk factor screening and counseling or other health education activities. Some of the programs were carried out in the workplace.

\section{INTERVENTIONS WITH INSUFFICIENT EVIDENCE TO BE RECOMMENDED}

The Task Force determined that there was insufficient evidence to recommend either for or against five additional interventions. Such a finding, nevertheless, was not evidence of ineffectiveness, the Task Force report noted. Insufficient evidence might be determined for one or more reasons, including an insufficient number of stud- ies, flaws with the available studies in terms of their design or execution, and conflicting study results. A finding of insufficient evidence could help identify areas of uncertainty and of needed research.

One of the interventions not recommended was classroom-based health education for children that primarily focused on providing information on health risks and behavioral risk factors related to physical activity, nutrition, smoking, and alcohol and drug abuse. The methods used were mainly didactic. The Task Force concluded that these kinds of interventions provided inconsistent evidence of an effect on physical activity behavior, aerobic fitness, or both.

A second intervention not recommended was the use of mass media campaigns as single-component interventions designed to increase knowledge, influence attitudes, and change behavior (in contrast to multicomponent communitywide informational campaigns, with their support groups, risk factor screening and education, and community events). These single-component mass media campaigns included paid advertising and donated promotions that were transmitted using newspapers, radio, television, and billboards, either singly or in combination.

Also not recommended were physical education and health education classes for college students. The classes could be either didactic or ones where the students engaged in physical activities. There was an inadequate number of studies on this approach for it to be recommended, the Task Force indicated.

A fourth intervention not recommended was classroom-based education that focused on reducing the amount of time spent watching television and playing video games. While some studies found decreases in television watching and video game playing, there was inconsistent or insufficient evidence that this led to increases in physical activity behavior and aerobic capacity.

A final approach not recommended was social support interventions in family settings. Such interventions included behavioral contracts among family members, goal-setting and problem-solving, and other behavioral management techniques. Some were school-based interventions, with takehome information packets, reward systems, and family record-keeping. There was insufficient evidence for the effectiveness of these kinds of interventions, the Task Force reported.

This review of increasing physical activity is one of a number of reviews of preventive health topics that the Task Force has completed. The individual Task Force Community Guide topics are prepared and released as each is completed. Ones that have already been published include vaccine- 
preventable diseases, tobacco use prevention and reduction, motor-vehicle occupant injury, and diabetes $(2,3)$. Among future topics will be alcohol abuse, sexual behavior, cancer, oral health, violence, and the sociocultural environment for health.

\section{SINOPSIS}

\section{Intervenciones para promover la salud mediante un aumento de la actividad física}

El ejercicio físico practicado con regularidad aporta varios beneficios para la salud, pero solamente una cuarta parte de los adultos en Estados Unidos de América hacen ejercicio en las cantidades recomendadas semanalmente. Además, muchos adultos y adolescentes en ese país dicen no practicar con regularidad un ejercicio físico moderado o intenso. Para ayudar a remediar esta situación, un grupo de salubristas estadounidenses llevó a cabo una revisión sistemática de in- tervenciones que podrían redundar en un aumento de la actividad física. El grupo, conocido por Grupo de Trabajo sobre Servicios Comunitarios Preventivos [Task Force on Community Preventive Services] fue convocado por el Departamento de Salud y Servicios Humanos del Gobierno de Estados Unidos, aunque es independiente de esta entidad. El Grupo de Trabajo recomendó dos enfoques informativos (campañas comunitarias y recordatorios en los puntos de decisión para fomentar el uso de escaleras), tres enfoques conductuales y sociales (educación física en las escuelas, intervenciones de apoyo social en contextos comunitarios, como un sistema de trabajo con pares o de pacto con otras personas para alcanzar niveles específicos de actividad física, y programas de modificación conductual de orientación individual); y una intervención orientada a aumentar la actividad física mediante un enfoque ambiental y político (creando o facilitando acceso a sitios donde hacer ejercicio, junto con actividades informáticas proactivas). El Grupo de Trabajo no encontró datos suficientes para recomendar o no cinco intervenciones adicionales.

\section{REFERENCES}

1 United States of America, Department of Health and Human Services. Healthy people 2010. 2nd ed. Washington, D.C.: Government Printing Office; 2000.
2. The Guide to Community Preventive Services. At a glance [Internet page]. Available from: http://www.thecommunity guide.org [Internet site]. Accessed 16 November 2001.
3. Estrategias para reducir la morbilidad y mortalidad de la diabetes. Rev Panam Salud Publica 2001;11(5):354-357. 